\title{
Pengaruh Budaya Organisasi dan Good Corporate Governance terhadap Kinerja Karyawan di RSUD K.H. Daud Arif Kuala Tungkal Jambi
}

\author{
Azizah, Muhammad Emmil \\ Fakultas Ekonomi Universitas Batanghari Jambi \\ Correspondence email: muhammademil@gmail.com
}

\begin{abstract}
Abstrak_ Tujuan spesifik dan terperinci dari penelitian ini anatara lain untuk menganalisa pengaruh secara parsial dan simultan budaya organisasi dan Good Corporate Governance terhadap kinerja karyawan di RSUD K.H. Daud Arif Kuala Tungkal Jambi. Metode yang digunakan adalah penelitian kuantitatif dengan rancangan penelitian yang digunakan adalah penelitian survei untuk tujuan deskriptif dan eksplanatif. Populasi sebanyak 342 pegawai dan dilakukan tehnik penarikan sampel secara non probability. Sampel dalam penelitian ini diambil 10\% dari jumlah populasi, sehingga jumlah sampelnya sebanyak 34 pegawai. Teknik analisis data yang digunakan dalam penelitian ini adalah analisis regresi linier berganda. Hasil penelitian menunjukan bahwa 1) secara parsial telah diperoleh perhitungan dan pembahasan bahwa variabel budaya organisasi (X1) berpengaruh positif secara signifikan terhadap kinerja karyawan $(Y)$ dimana hasil perhitungan menunjukan $t$ hitung sebesar 3,349 > t tabel sebesar 1,697 sehingga HO ditolak dan HI diterima dan untuk variabel good corporate governance (X2) menunjukan ada pengaruh yang signifikan terhadap kinerja karyawan (Y), diperoleh perhitungan t hitung sebesar 2,067 > t tabel 1,697 sehingga HO ditolak dan H1 diterima, dan 2) secara simultan budaya organisasi (X1) dan good corporate governance (X2), beperngaruh signifikan terhadap kinerja karyawan (Y), diperoleh perhitungan F hitung sebesar 7,643 > F tabel 3,30 sehingga HO ditolak dan HI diterima.
\end{abstract}

Kata kunci: budaya organisasi, good corporate governance, kinerja karyawan

\begin{abstract}
_specific and detailed objectives of this study are another way to analyze the partial and simultaneous influence of organizational culture and Good Corporate Governance on employee performance at K.H. Daud Arif Kuala Tungkal Jambi Hospital. The method used is quantitative research with the design of the research used is survey research for descriptive and expansive purposes. The population of 342 employees and the technique of withdrawal of samples on a non probability. The sample in this study was taken $10 \%$ of the population, resulting in a sample of 34 employees. The data analysis technique used in this study is multiple linear regression analysis. The results showed that 1) partially obtained calculations and discussions that the cultural variables of the organization (X1) had a significant positive effect on employee performance (Y) where the calculation results showed a t count of 3,349 > t table of 1,697 to $\mathrm{HO}$ rejected and $\mathrm{H} 1$ accepted and for good corporate governance variables (X2) shows there is a significant influence on employee performance (Y), obtained calculation t count of 2,067 > t table 1,697 so that $\mathrm{HO}$ is rejected and $\mathrm{H} 1$ is accepted, and 2) simultaneously organizational culture (X1) and good corporate governance (X2), a significant impact on employee performance $(Y)$, obtained a calculation of F count of 7,643 > F table 3.30 so that HO is rejected and $\mathrm{H} 1$ is accepted.
\end{abstract}

Keywords: organizational culture, good corporate governance, employee performance

\section{PENDAHULUAN}

Sumber daya manusia merupakan faktor yang sangat penting dalam sebuah organisasi baik organisasi dalam skala besar maupun kecil. Pada organisasi berskala besar, sumber daya manusia dipandang sebagai unsur yang sangat menentukan dalam proses pengembangan usaha, perkembangan dunia usaha akan terealisasi apabila ditunjang oleh sumber daya manusia yang berkualitas. Usaha memenuhi tuntutan kualitas sumber daya manusia sebagai mana disebutkan di atas sangat penting bagi suatu organisasi, terutama organisasi yang bergerak dalam bidang pelayanan. Hal ini dikarenakan organisasi pelayanan berkaitan langsung dengan orang-orang yang membutuhkan pelayanan. Peningkatan pelayanan ini harus terorganisir dengan baik dimulai dari pimpinan sampai bawahanya menunjukan kinerja yang optimal. Untuk menciptakan kinerja yang optimal diperlukan suatu budaya organisasi sebagai acuan atau pedoman kerja bagi karyawan dalam menjalankan berbagai aktivitas perusahaan atau organisasi. Seperti yang dikemukakan oleh Susanto (2006:109) bahwa untuk menciptakan kinerja karyawaan yang efektif dan efesien demi keberlangsungan sutu organisasi diperlukan budaya organisasi sebagai pedoman dalam menjalankan aktivitas organisasi.

Berdasrkan pada konteks tentang pemberdayaan sumber daya manusia supaya dapat menciptakan kinerja karyawan yang handal dan profesional serta berintegritas tinggi diperlukan acuan baku yang dibentuk oleh suatu organisasi atau perusahaan. Acuan baku tersebut dapat berupa budaya organisasi yang secara terstruktur dan sistematis mengharuskan para karyawan untuk meningkatkan hasil kinerjanya bagi organisasi atau perusahaan dimana mereka bekerja. Budaya organisasi meresap dan merasuk pada sendi-sendi kehidupan berorganisasi yang akan mempengaruhi jalanya aktivitas kehidupan organisasi tersebut. Oleh sebab itu, budaya organisasi sangat penting diterapkan pada berbagai aspek fundamental dari kinerja organisasi. Untuk itu, budaya organisasi harus dikelola dan dijalankan dengan 
apik sehingga dapat meningkatkan kinerja para karyawan. Menurut Robbins dan Judge dalam Wibowo (2010:256) menyatakan bahwa budaya oranisasi mengacu ke sistem makna bersama yang dianut oleh anggota-anggota yang membedakan organisasi itu dari organisasi-organisasi lain. Sistem maksa bersama ini, bila diamati dengan lebih seksama, merupakan seperangkat karakteristik utama yang dihargai oleh organisasi itu. Budaya organisasi akan mempengaruhi kinerja karyawan yang dapat menaikan koordinasi antar karyawan. Sebagaimana diketahui kinerja (performance) adalah hasil kerja yang dapat dicapai oleh seorang atau sekelompok orang dalam suatu organisasi, sesuai dengan wewenang dan tanggung jawab masing-masing dalam rangka mencapai tujuan organisasi yang bersangkutan secara legal yang tidak melanggar hukum dan sesuai dengan moral maupun etika (Lilis, 2009: 239).

Tak hanya dari sisi budaya organisasi yang harus diperhatikan oleh suatu organisasi atau perusahaan dalam meningkatkan kinerja karyawaan. Sebagai salah satu upaya untuk mengatasi permasalahan-permasalahan yang banyak terjadi pada perusahaan di Indonesia, maka para pelaku bisnis di Indonesia menyepakati penerapan Good Corporate Governance (GCG) atau yang biasa dikenal dengan sistem tata kelola perusahaan yang baik. Good Corporate Governance (GCG) pada dasarnya merupakan suatu sistem (input, proses, output) dan seperangkat peraturan yang mengatur hubungan antara berbagai pihak yang berkepentingan (stakeholders) demi tercapainya tujuan perusahaan. GCG dimasukkan untuk mengatur hubungan-hubungan tersebut dan mencegah terjadinya kesalahan yang signifikan dalam strategi perusahaan dan untuk memastikan bahwa kesalahankesalahan yang terjadi dapat diperbaiki dengan segera (Zarkasyi, 2008:12). Apabila kesalahan-kesalahan dalam aktivitas kegiatan perusahaan bisa diatasi tentunya akan berdampak pada kinerja dari karyawan pada perusahaan tersebut. Hal ini menunjukan kualitas dari sumber daya manusia yang dimilki suatu perusahaan.

Perkembangan dunia usaha yang semakin pesat akan menciptakan daya saing untuk merebut pangsa pasar yang lebih luas. Untuk itu diperlukan sumber daya manusia yang memiliki kinerja yang optimal dalam menjalankan aktivitas organisasi dengan memberikan suatu pelayanan yang memuaskan bagi konsumen. Mengingat tentang memberikan pelayanan, tentu sering kita rasakan dalam kehidupan sehari-hari terutama dalam menggunakan fasilitas-fasilitas kesehatan yang ada salah satunya adalah rumah sakit. Rumah sakit sebagai institusi yang bergerak di bidang pelayanan kasehatan mengalami perubahan, pada awal perkembangannya, rumah sakit adalah lembaga yang berfungsi sosial, tetapi dengan adanya rumah sakit swasta, menjadikan rumah sakit lebih mengacu sebagai suatu industri yang bergerak dalam bidang pelayanan kesehatan dengan melakukan pengelolaan yang berdasar pada manajemen badan usaha. Seiring dengan itu, terjadi persaingan antara sesama rumah sakit baik rumah sakit milik pemerintah maupun rumah sakit milik swasta, semua berlombalomba untuk menarik konsumen agar menggunakan jasanya.

Kedudukan RSUD K.H. Daud Arif Kuala Tungkal Jambi merupakan Lembaga Teknis Daerah sebagai unsur penunjang Pemerintah Daerah, dipimpin oleh seorang Direktur dan bertanggung jawab kepada Gubernur melalui Sekretaris Daerah. Dimana karyawan di RSUD K.H. Daud Arif Kuala Tungkal Jambi terdiri dari pegawai tenaga medis dan pegawai paramedis sebagai ujung tombak dalam pelaksanaan pelayanan bidang kesehatan merupakan pihak yang sangat berpengaruh dalam proses pelayanan kesehatan. Kecakapan dan keterampilan paramedis sangat menentukan kelangsungan proses pelayanan kesehatan di rumah sakit maupun efeknya di luar rumah sakit. Tenaga medis maupun paramedis harus pandai memberikan sugesti kepada tujuan yang hendak dicapai, yaitu memberikan pelayanan kesehatan kepada masyarakat yang berkualitas dan terjangkau. Untuk melaksanakan apa yang menjadi tanggung jawabnya, maka RSUD K.H. Daud Arif Kuala Tungkal Jambi mempunyai visi dan misi. Dimana visi adalah suatu gambaran dan harapan yang menantang tentang keadaan masa depan yang berisikan cita dan citra yang ingin diwujudkan oleh suatu organisasi atau pandangan jauh kedepan, kemana dan bagaimana suatu organisasi akan dibawa dan berkarya agar tetap eksis, antisipatif, responsif, inovatif serta produktif. Sedangkan misi adalah sesuatu yang harus diemban dan dilaksanakan oleh organisasi agar tujuannya dapat terlaksana dan berhasil dengan optimal serta sesuai dengan visi yang diinginkan.

RSUD K.H. Daud Arif Kuala Tungkal Jambi merupakan salah satu fasilitas kesehatan milik daerah di Kuala Tungkal. Namun, masyarakatnya belum banyak memanfaatkan fasilitas kesehatan di rumah sakit tersebut. Masih banyak warga masyarakatnya untuk mempercayakan kesehatan mereka pada rumah sakit lain yang ada di Kota Jambi. Hal ini terjadi karena masyarakat merasa pelayanan yang diberikan oleh rumah sakit tersebut belum memuaskan para pasein atau konsumen dikarenakan keterbatasan-keterbatasan fasilitas yang dimilki. Selain permasalahan dari segi pelayanan, rumah sakit ini pun memilki kinerja yang belum mencapai target yang diharapkan manajemen rumah sakit.

Dari pengamatan yang penulis lakukan selama ini ternyata masih banyak masalah yang terjadi berkaitan dengan kinerja karyawan medis dan paramedis di RSUD K.H. Daud Arif Kuala Tungkal Jambi. Ini terlihat antara lain dari hasil pencapaian kegiatan yang di kemudian dibandingkan dengan target yang telah ditetapkan sebelumnya. Hasil pencapaian program dapat dilihat pada tabel di bawah ini: 
Azizah dan Muhammad Emmil, Pengaruh Budaya Organisasi dan Good Corporate Governance terhadap Kinerja Karyawan di RSUD K.H. Daud Arif Kuala Tungkal Jambi

Tabel 1. Laporan LAKIP RSUD K.H. Daud Arif Kuala Tungkal Jambi

\begin{tabular}{|c|c|c|c|c|c|}
\hline No & Target Kerja & Indikator Target Kerja & $\begin{array}{l}\text { Rencana } \\
\text { (Target) }\end{array}$ & $\begin{array}{l}\text { Persentase } \\
\text { Rencana } \\
\text { terRealisasi }\end{array}$ & $\begin{array}{c}\text { Persentase } \\
\text { Rencana } \\
\text { yang belum } \\
\text { terRealisasi }\end{array}$ \\
\hline 1 & $\begin{array}{l}\text { Terwujudnya rumah sakit } \\
\text { yang sesuai dengan } \\
\text { program pembangunan } \\
\text { yang telah disusun } \\
\text { berdasarkan master plan } \\
\text { untuk memberikan } \\
\text { pelayanan pada pasien } \\
\text { secara efektif dan efesien }\end{array}$ & $\begin{array}{llr}\text { - } & \text { Terwujudnya penambahan } \\
\text { ruangan untuk memperluas } \\
\text { ruangan yang sudah ada } \\
\text { - } & \text { Terwujudnya bantuan } \\
\text { pemerintah dalam } \\
\text { pengadaan dana sepenuhnya } \\
\text { untuk pengembangan rumah } \\
\text { sakit }\end{array}$ & $\begin{array}{l}\text { - } 100 \% \\
\text { - Penambahan } \\
\text { ruangan untuk pasien } \\
\text { rawat inap } \\
\text { - Bantuan dana hanya } \\
1 / 4 \text { dari dana yang } \\
\text { diajukan } \\
\text { pembangunan rumah } \\
\text { sakit dari pemerintah }\end{array}$ & $\begin{array}{c}100 \% \\
\text { Belum } \\
\text { terlaksana }\end{array}$ & $0 \%$ \\
\hline 2 & $\begin{array}{ll}\text { Terpenuhinya } & \text { alat } \\
\text { kesehatan Medis dan non } \\
\text { Medis. }\end{array}$ & $\begin{array}{l}\text { - Tersedianya peralatan } \\
\text { kedokteran umum, bedah, } \\
\text { kardiologi, internis, non } \\
\text { medis seperti komputer AC } \\
\text { dll, serta peralatan } \\
\text { perawatan dasar rumah sakit }\end{array}$ & $\begin{array}{l}\text { 100\% } \\
\begin{array}{l}\text { Peralatan kedokteran } 10 \\
\text { unit }\end{array} \\
\text { Peralatan non medis } \\
\text { masing-masing } 15 \text { unit }\end{array}$ & $\begin{array}{l}\text { 75\% } \\
\text { Yang terealisasi } \\
6 \text { unit } \\
\text { Terealisasi } \\
\text { masing-masing } \\
8 \text { unit }\end{array}$ & $\begin{array}{c}25 \% \\
\\
\text { Tidak } \\
\text { terealisasi }\end{array}$ \\
\hline 3 & $\begin{array}{l}\text { Terpenuhinya obat-obatan } \\
\text { bahan habis pakai }\end{array}$ & $\begin{array}{l}\text { - Terlaksananya pemberian } \\
\text { pelayanan pasien IGD, } \\
\text { Operasi dan rawat inap }\end{array}$ & $\begin{array}{l}\text { } 100 \% \\
\text { Pemberian pelayanan } \\
\begin{array}{l}\text { optimal pada seluruh } \\
\text { pasien }\end{array}\end{array}$ & $\begin{array}{c}80 \% \\
\text { Tereliasi }\end{array}$ & $\begin{array}{c}20 \% \\
\text { Tidak } \\
\text { terealisasi }\end{array}$ \\
\hline 4 & $\begin{array}{l}\text { Terlaksananya penataan } \\
\text { dan pengembangan SDM } \\
\text { berdaya saing }\end{array}$ & $\begin{array}{llr}\text { - } & \text { Tersusunnya perangkat } \\
\text { peraturan kepegawaian yang } \\
\text { kondusif } & \text { bagi } \\
\text { pengembangan SDM } & \end{array}$ & $\begin{array}{l}\text { Semua } 100 \% \\
\text { peraturan penataan, } \\
\text { pengembanganSDm dan } \\
\text { pegawai dikondusfkan }\end{array}$ & \begin{tabular}{l}
\multicolumn{2}{c}{$85 \%$} \\
Terealisasi \\
hanya pada \\
penataan dan \\
peraturan \\
kepegawaian \\
\end{tabular} & $\begin{array}{c}15 \% \\
\text { Tidak } \\
\text { terealisasi }\end{array}$ \\
\hline 5 & $\begin{array}{l}\text { Terpeliharanya sarana dan } \\
\text { prasarana RSUD Raden } \\
\text { Mattaher Jambi }\end{array}$ & $\begin{array}{l}\text { - } \begin{array}{l}\text { Terpeliharanya perangkat } \\
\text { sarana dan prasarana }\end{array} \\
\text { sana }\end{array}$ & $\begin{array}{lc} & 100 \% \\
\text { Semua } & \text { terawat dengan } \\
\text { baik } & \end{array}$ & $\begin{array}{c}85 \% \\
\text { Ada perangkat } \\
\text { yang harus } \\
\text { diperbaiki }\end{array}$ & $\begin{array}{c}15 \% \\
\text { Tidak } \\
\text { terealisasi } \\
\end{array}$ \\
\hline
\end{tabular}

Sumber : RSUD K.H. Daud Arif Kuala Tungkal Jambi 2019

Dari tabel di atas terlihat bahwa terjadi kesenjangan antara target dan pencapaian kegiatan program RSUD K.H. Daud Arif Kuala Tungkal Jambi. Rendahnya kinerja dari RSUD K.H. Daud Arif Kuala Tungkal Jambi tersebut juga didasarkan dari rendahnya kinerja para karyawan dalam melaksanakan pekerjaannya. Data yang ditampilkan pada tabel tersebut adalah merupakan hasil representatif terhadap kinerja para karyawan RSUD K.H. Daud Arif Kuala Tungkal Jambi, dimana ada lima program yang dicanangkan oleh RSUD K.H. Daud Arif Kuala Tungkal Jambi hanya satu program yang terrealisasi sedangkan terdapat emapat program yang belum begitu optimal dimana pada sasaran terpenuhinya alat kesehatan medis dan non medis yaitu terrealisasi $75 \%$, pada sasaran terpenuhinya obat-obatan bahan habis pakai yaitu terrealisasi $80 \%$, terlaksananya penataan dan pengembangan SDM berdaya saing yang terlealisasi $85 \%$, dan terpeliharanya sarana dan prasarana RSUD K.H. Daud Arif Kuala Tungkal Jambi terrealisasi 85\%.

Belum optimalnya kinerja para karyawan di RSUD K.H. Daud Arif Kuala Tungkal Jambi sebagaimana diuraikan di atas, banyak sekali faktor yang dapat mempengaruhinya, salah satu yang diduga adalah rendahnya penerapan fungsi budaya organisasi dalam aktivitas kegiatan yang dilakukan oleh karyawan RSUD K.H. Daud Arif Kuala Tungkal Jambi. Penerapan budaya organisasi dalam suatu lembaga sangat penting, karena dengan memilki acuan penerapan budaya organisasi yang telah ditentukan oleh manajemen RSUD K.H. Daud Arif Kuala Tungkal Jambi, maka karyawan akan melakukan kinerjanya berdasarkan budaya organisasi yang diterapkan tersebut. Namun, dalam keseharian kinerja karyawan belum melaksanakan secara penuh budaya organisasi tersebut sehingga menimbulkan suatu permasalahan yang berdampak pada kualitas pelayanan yang diberikan.

Permasalahan-permasalahan yang terjadi dari segi pelayanan yang diberikan karyawan RSUD K.H. Daud Arif Kuala Tungkal Jambi, bisa diatasi apabila rumah sakit tersebut memilki tata kelola yang baik atau Good Corporate Governance (GCG) dalam menangani permasalahan yang terjadi. Melalui Good Corporate Governance (GCG) manajemen RSUD K.H. Daud Arif Kuala Tungkal Jambi melakukan rangkaian proses terstruktur yang digunakan untuk mengelola serta 
mengarahkan atau memimpin bisnis dan usaha-usaha korporasi dengan tujuan untuk meningkatkan nilai-nilai perusahaan serta kontinuitas usaha. Sehingga, hal tersebut dapat meningkatkan kinerja karyawan dengan memaksimalkan pelayanan yang berkualitas bagi pasien atau konsumen.

Disebabkan kurang adanya penerapan budaya organisasi dalam menciptakan kondisi kerja yang harmonis serta memberikan pembinaan pada karyawan akan menyebabkan tingkat kinerja karyawan rendah. Demikian halnya dengan kurangnya penerapan Good Corporate Governance (GCG) seperti tidak menjalankan tata kelola tentang nilai-nilai perusahaan dengan baik, malas-malasan dalam bekerja akan menyebabkan kinerja karyawan rendah. Hal ini terlihat pada RSUD K.H. Daud Arif Kuala Tungkal Jambi bahwa tingkat kinerja belum optimal dikarenakan dalam praktek dilapangan pihak RSUD K.H. Daud Arif Kuala Tungkal Jambi kurang menerapkan budaya organisasi dan Good Corporate Governance (GCG) yang harmonis diantara pimpinan dengan bawahan, serta kurangnya perhatian sesama karyawan sebagai salah satu dari budaya organisasi yang menyebabkan semangat karyawan rendah dan berakibat menurunnya kinerja karyawan. Mengingat pentingnya masalah tersebut dan untuk menyikapi kondisinya dirumuskan suatu tujuan spesifik dan terperinci dari penelitian ini yaitu (1) Untuk mengetahui pengaruh budaya organisasi terhadap kinerja karyawan di RSUD K.H. Daud Arif Kuala Tungkal Jambi. (2) Untuk mengetahui pengaruh Good Corporate Governance (GCG) terhadap kinerja karyawan di RSUD K.H. Daud Arif Kuala Tungkal Jambi. (3) Untuk mengetahui pengaruh budaya organisasi dan Good Corporate Governance (GCG) terhadap kinerja karyawan di RSUD K.H. Daud Arif Kuala Tungkal Jambi.

\section{Kinerja}

Landasan yang amat penting bagi keberlangsungan suatu organisasi atau perusahaan adalah kinerja. Menurut Harsuko (2011) menyatakan bahwa kinerja itu adalah sejauh mana seseorang telah memainkan baginya dalam melaksanakan strategi organisasi, baik dalam mencapai sasaran khusus yang berhubungan dengan peran perorangan dan atau dengan memperlihatkan kompetensi yang dinyatakan relevan bagi organisasi. Lebih lanjut Mangkunegara (2011:67) mengungkapkan tentang kinerja itu adalah prestasi kerja atau hasil kerja secara kualitas dan kuantitas yang dicapai oleh seseorang pegawai dalam melaksanakan tugasnya sesuai dengan tanggung jawab yang diberi kepadanya. Sehingga menurut Sinambela (2012) kinerja karyawan didefinisikan sebagai kemampuan pegawai dalam melakukan sesuatu keahlian tertentu. Lebih lanjut

Tinggi rendahnya kinerja karyawan pada dasarnya merupakan hasil pengaruh dari faktor-faktor yang mempengaruhinya. Seperti yang dikemukakan, Walker et.al (2012: 186), terdapat empat faktor utama yang dianggap sebagai penentu perilaku karyawan di tempat kerja yang menghasilkan kinerja diantaranya:

"Four principal factors are identified as determining employee behavior at work, and thus performance results. Performance objective are critical, as they provide the direction for effort: What is to be accomplished and how will we know it is accomplished? The structure and content of work activities is the second key factor: job design, organization structure, and working relationship. Third, the skills, abilities, and knowledgecompetencies-of the individuals are critical as a performance factor. And finally, rewards are necessary as incentives and recognition of performance".

Penetapan indikator penilaian kinerja yang berkualitas adalah standard minimum yang harus dilakukan oleh organisasi dalam pencapaian tujuannya Menurut Prawirosentono (2010: 27), kinerja dapat dinilai atau diukur dengan beberapa indikator yaitu:

a) Efektifitas Efektifitas yaitu bila tujuan kelompok dapat dicapai dengan kebutuhan yang direncanakan.

b) Tanggung jawab merupakan bagian yang tak terpisahkan atau sebagai akibat kepemilikan wewenang.

c) Disiplin yaitu taat pada hukum dan aturan yang belaku. Disiplin karyawan adalah ketaatan karyawan yang bersangkutan dalam menghormati perjanjian kerja dengan perusahaan dimana dia bekerja.

d) Inisiatif yaitu berkaitan dengan daya pikir, kreatifitas dalam bentuk suatu ide yang berkaitan tujuan perusahaan. Sifat inisiatif sebaiknya mendapat perhatian atau tanggapan perusahaan dan atasan yang baik. Dengan perkataan lain inisiatif karyawan merupakan daya dorong kemajuan yang akhirnya akan mempengaruhi kinerja karyawan.

\section{Budaya Organisasi}

Manusia adalah makhluk yang berbudaya, setiap aktifitasnya mencerminkan sistem kebudayaan yang berintegrasi dengan dirinya, baik cara berpikir, memandang sebuah permasalahan. Pengambilan keputusan dan lain sebagainya. Seiring dengan bergulirnya waktu, budaya pasti terbentuk dalam organisasi dan dapat pula dirasakan manfaatnya dalam memberi kontribusi bagi efektivitas organisasi secara keseluruhan. Luthans (2011:137) mengemukakan bahwa budaya organisasi adalah pola pemikiran dasar yang diajarkan kepada personel baru sebagai cara untuk merasakan, berfikir dan bertindak secara benar dari harikehari. Definisi budaya organisasi menurut Kinicki dan Fugate (2013:32) adalah

"Organizational culture is the set of shared, taken for
granted implicit
assumptions that a group holds and that determines
how it perceives,
thinks about, and reacts to its various environments."


Selanjutnya Menurut Robbins dan Judge (2013:512) definisi budaya organisasi adalah sebagai berikut:

"Organizational culture refers to a system of shared meaning held by

members that distinguishes the organization from other organizations."

Robbins dan Judge (2008:256-257) mengemukakan, bahwa budaya organisasi memiliki karakteristik kunci yang dijunjung tinggi oleh organisasi. Karakteristik tersebut secara keseseluruhan merupakan hakikat budaya. Adapun karakteristik tersebut meliputi: a. Inovasi dan keberanian mengambil risiko, b. Perhatian pada hal-hal rincian, c. Orientasi hasil, d. Orientasi orang, e. Orientasi tim, f. Keagresifan, dan e. Stabilitas.

Sedangkan Amnuai dan Schien (2014) membagi budaya organisasi kedalam beberapa indikator yaitu antara lain a). Aspek kualitatif (basic), b). Aspek kuantitatif (shared) dan aspek terbentuknya. c). Aspek komponen (assumption dan beliefs), d). Aspek adaptasi eksternal (eksternal adaptation), dan e). Aspek Integrasi internal (internal integration) sebagai proses penyatuan budaya melalui asimilasi dari budaya organisasi yang masuk dan berpengaruh terhadap karakter anggota.

\section{Good Corporate Governance (GCG)}

Perspektif hubungan keagenan merupakan dasar yang digunakan untuk memahami corporate governance. Good Corporate Governance merupakan sistem yang mengatur dan mengendalikanperusahaan yang menciptakan nilai tambah (valueadded) untuk semua stakeholders (Monks dan Minow, 2003). Tata kelola perusahaan juga mencakup hubungan antara para pemangku kepentingan (stakeholder) yang terlibat serta tujuan pengelolaan perusahaan. Pihak-pihak utama dalam tata kelola perusahaan adalah pemegangsaham, manajemen, dan dewan direksi (Wibowo, 2011). Kurniawan (2012:27) mendefinisikan Good Corporate Governance adalah seperangkat hubungan yang terjadi antara manajemen, direksi, pemegang saham dan stakeholder-stakeholder lain seperti pegawai, kreditor dan masyarakat.

Good Corporate Governance (GCG) pada dasarnya merupakan sistemyang mengatur, mengelola, dan mengawasi proses pengelolaan usaha untukmelancarkan hubungan antar manajemen, pemegang saham, dan pihak lainnnyayang berkepentingan, tujuannya untuk menciptakan nilai tambah bagi perusahaan (Pratiwi, 2016). Menurut Tunggal (2012:24) pengertian Good Corporate Governance adalah sistem yang mengatur, mengelola dan mengawasi proses pengendalian usaha untuk menaikan nilai saham, sekaligus sebagai bentuk perhatian kepada stakeholders, karyawan dan masyarakat sekitar. Adapun bobot nilai yang digunakan untuk menilai GCG (Good Corporate Governance) menurut Indonesian Institue of Corporate Governance
(IICG) (dalam Reny dan Denies, 2012) terdapat empat tahapan penilaian sebagai persyaratan penilaian yang wajib diikuti oleh peserta CGPI yakni a) Self Assessment, b) Kelengkapan dokumen, c) Penyusunan makalah dan presentasi, dan d) Observasi

\section{Hipotesis}

Adapun yang menjadi hipotesa dalam penelitian ini adalah sebagai berikut:

1) Ho : Tidak ada pengaruh budaya organisasi dan Good Corporate Governance

secara parsial terhadap kinerja karyawan

RSUD K.H. Daud Arif Kuala

Tungkal Jambi.

Ha : Terdapat pengaruh budaya organisasi dan Good Corporate Governance

secara parsial terhadap kinerja karyawan

RSUD K.H. Daud Arif Kuala

Tungkal Jambi.

2) Ho : Tidak ada pengaruh budaya organisasi dan

Good Corporate Governance

secara simultan terhadap kinerja karyawan

RSUD K.H. Daud Arif Kuala

Tungkal Jambi.

$\mathrm{Ha}$ : Terdapat pengaruh budaya organisasi dan Good Corporate Governance

secara simultan terhadap kinerja karyawan

RSUD K.H. Daud Arif Kuala

Tungkal Jambi.

\section{METODE}

Penelitian ini menggunakan metode penelitian kuantitatif dengan rancangan penelitian yang digunakan adalah penelitian survei untuk tujuan deskriptif dan eksplanatif. Tujuan deskriptif adalah untuk menggambarkan berbagai karateristik dari fenomena yang diamati, misalnya dalam penelitian ini mengenai budaya organisasi, Good Corporate Governance dan kinerja karyawan medis dan paramedis. Tujuan eksplanatif adalah untuk menjelaskan hubungan sebab akibat diantara variabel-variabel yang dilibatkan dalam penelitian. Berdasarkan tujuan deskriptif dan eksplanatif tersebut dapat digambarkan model penelitian empirik pada gambar 1 dibawah ini:

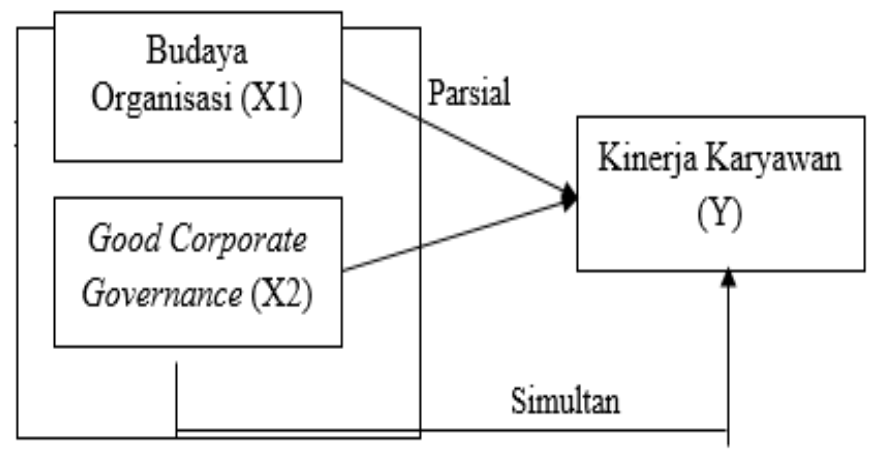

Gambar 1. Model Penelitian 
Populasi dalam penelitian ini adalah seluruh karyawan medis dan paramedis di RSUD K.H. Daud Arif Kuala Tungkal Jambi sebanyak 342 pegawai. Mengingat unit analisis bersifat heterogen baik dari sisi golongan, kepangkatan, jabatan dan masa kerja, bidang kerja, tingkat pendidikan maupun tingkat pendapatan, maka tehnik penarikan sampel dilakukan secara non probability. Sampel dalam penelitian ini diambil $10 \%$ dari jumlah populasi, sehingga jumlah sampelnya sebanyak 34 pegawai. Alat ukur yang digunakan dengan melakukan penyebaran kuisioner pada para pegawai yang menjadi sampel dengan rentang nilai skala likert. Teknik analisis data yang digunakan dalam penelitian ini adalah analisis regresi linier berganda untuk menghitung uji parsial ataupun simultan dengan bantuan program komputer SPSS versi 23.

\section{HASIL DAN PEMBAHASAN}

Untuk menjawab tujuan dari penelitian ini, telah dilakukan uji pengaruh budaya organisasi, Good Corporate Governance terhadap kinerja karyawan di RSUD K.H. Daud Arif Kuala Tungkal Jambi baik secara parsial ataupun simultan. Hasil Penelitian ini dihitung menggunakan teknik analisis data regresi linier berganda yang dapat diketahui pada tabel 1 berikut ini:

Tabel 2. Analisis Regresi Linier Berganda Coefficients $^{\mathrm{a}}$

\begin{tabular}{|c|c|c|c|c|c|c|}
\hline \multirow{2}{*}{\multicolumn{2}{|c|}{ Model }} & \multicolumn{2}{|c|}{ Unstandardized Coefficients } & \multirow{2}{*}{$\frac{\text { Standardized Coefficients }}{\text { Beta }}$} & \multirow[b]{2}{*}{$\mathrm{t}$} & \multirow[b]{2}{*}{ Sig. } \\
\hline & & $\mathrm{B}$ & Std. Error & & & \\
\hline 1 & (Constant) & 19,932 & 16,504 & & 1,208 & 236 \\
\hline & Budaya Organisasi & ,685 & ,205 & ,569 & 3,349 & ,002 \\
\hline & GCG & ,113 & 202 & ,111 & 2,067 & ,047 \\
\hline
\end{tabular}

a. Dependent Variable: Kinerja Karyawan

Analisis regresi linier berganda yang digunakan dalam penelitian ini dapat dirumuskan $\mathbf{Y}=\boldsymbol{\alpha}+\boldsymbol{\beta}_{\mathbf{1}} \mathbf{X}_{\mathbf{1}}+$ $\boldsymbol{\beta}_{2} \mathbf{X}_{2}+$ e. Output analisis regresi linier berganda pada tabel 1 diperoleh persamaan $\mathrm{Y}=19,932+0,685 \mathrm{X}_{1}+$ $0,113 \mathrm{X}_{2}+$ e. Dari model regresi tersebut dapat dijelaskan makna tentang model analisis regresi linear berganda sebagai berikut:

1. Nilai konstanta sebesar 19,932 artinya apabila variabel independen yaitu budaya organisasi $\left(\mathrm{X}_{1}\right)$ dan Good Corporate Governance $\left(\mathrm{X}_{2}\right)$ bernilai nol (0), maka variabel dependen (Y) yaitu kinerja karyawan akan bernilai tetap sebesar 19,932.

2. Koefisien regresi variabel budaya organisasi $\left(\mathrm{X}_{1}\right)$ dan Good Corporate Governance $\left(\mathrm{X}_{2}\right)$ bernilai positif. Masing-masing nilai variabel independent tersebut sebesar $0,685 \mathrm{X}_{1}$ dan $0,113 \mathrm{X}_{2}$ artinya apabila variable budaya organisasi $\left(\mathrm{X}_{1}\right)$ dan Good Corporate Governance $\left(\mathrm{X}_{2}\right)$ mengalami peningkatan sebesar 1 (satu) satuan sedangkan variabel lainnya dianggap konstan, maka variabel Y yaitu kinerja karyawan akan mengalami peningkatan sebesar 0,685 atau $68,5 \%$ untuk variabel variable budaya organisasi $\left(\mathrm{X}_{1}\right)$ dan 0,113 atau $11,3 \%$ untuk variabel Good Corporate Governance $\left(\left(\mathrm{X}_{2}\right)\right.$. (kalau positif, Variabel $\mathrm{X}$ Meningkat dan Variabel Y meningkat)

Untuk mengukur seberapa jauh kemampuan model dalam menerangkan variabel-variabel dependen digunakan uji koefesien determinasi $\left(\mathrm{R}^{2}\right)$. Nilai koefisien adalah nol sampai dengan satu dan ditunjukkan dengan nilai adjusted $\mathrm{R}^{2}$. Pada tabel 2 berikut ini akan disajikan hasil koefesien determinasi yang dilihat dari $R$ Square dari model Summary yang digunakan:

Tabel 3. Koefesien Determinasi $\left(\mathbf{R}^{2}\right)$. Model Summary

\begin{tabular}{|c|c|c|c|c|}
\hline Model & R & R Square & Adjusted R Square & Std. Error of the Estimate \\
\hline 1 &, $575^{\mathrm{a}}$ &, 330 &, 287 & 4,033 \\
\hline
\end{tabular}

a. Predictors: (Constant), GCG, Budaya organisasi

Hasil output pengujian koefisien determinasi pada tabel 2, menunjukkan bahwa nilai $\mathrm{R}$ Square sebesar 0,330 yang artinya bahwa besarnya kontribusi variabel independen yaitu budaya organisasi $\left(\mathrm{X}_{1}\right)$ dan Good Corporate Governance $\left(\mathrm{X}_{2}\right)$ mempengaruhi variable kinerja karyawan $(\mathrm{Y})$ sebesar $(0,330 \times 100=33 \%)$, sedangkan sisanya $(100 \%-33 \%=67 \%)$ dipengaruhi oleh variabel-variabel lain di luar penelitian ini.

Perhitungan selanjutnya untuk menjawab hipotesa pertama dari tujuan penelitian terdapat pengaruh atau tidaknya variabel budaya organisasi $\left(\mathrm{X}_{1}\right)$ dan Good Corporate Governance $\left(\mathrm{X}_{2}\right)$ secara parsial terhadap kinerja karyawan di RSUD K.H. Daud Arif Kuala Tungkal Jambi digunakan perhitungan uji hipotesa yang dilihat dari besarnya uji t pada tabel 3 berikut: 
Tabel 4. Uji Parsial (Uji t)

\begin{tabular}{|l|c|r|}
\hline \multicolumn{1}{|c|}{ Model } & $\mathrm{t}$ & \multicolumn{1}{c|}{ Sig. } \\
\hline $1 \quad$ (Constant & 1,208 &, 236 \\
Budaya Organisasi X1 & 3,349 &, 002 \\
Good Corporate Governance X2 & 2,067 &, 047 \\
\hline
\end{tabular}

a. Dependent Variable: Kinerja Karyawan

Uji t pada tabel diatas menunjukan perhitungan secara parsial sekaligus menjawab tujuan pertama dari penelitian ini yakni untuk mengetahui pengaruh Budaya organisasi $\left(\mathrm{X}_{1}\right)$ dan Good Corporate Governance $\left(\mathrm{X}_{2}\right)$ terhadap kinerja karyawan di RSUD K.H. Daud Arif Kuala Tungkal Jambi. Hasil penelitian ini menunjukkan bahwa variabel budaya organisasi $\left(\mathrm{X}_{1}\right)$, berpengaruh terhadap kinerja karyawan. Hal ini bisa dilihat dari hasil uji t yang diperoleh, dimana budaya organisasi $\left(\mathrm{X}_{1}\right)$, memiliki arah nilai positif yaitu 3,349 yang memilki nilai yang lebih besar dari t tabelnya sebesar 1.697 dengan nilai signifikansi sebesar 0,002 $<0,05$ yang artinya signifikan. Dengan demikian, budaya organisasi $\left(\mathrm{X}_{1}\right)$, berpengaruh terhadap kinerja karyawan $(\mathrm{Y})$. Selanjutnya hasil uji t untuk variabel Good Corporate Governance $\left(\mathrm{X}_{2}\right)$, memiliki arah nilai positif yaitu 2,067 yang memilki nilai yang lebih besar dari t tabelnya sebesar 1.697 dengan nilai signifikansi sebesar 0,047 < 0,05 yang artinya signifikan. Dengan demikian, budaya organisasi $\left(\mathrm{X}_{1}\right)$ berpengaruh terhadap kinerja karyawan (Y). Demikian juga untuk variabel Good Corporate Governance $\left(\mathrm{X}_{2}\right)$ berpengaruh terhadap kinerja karyawan (Y). Sehingga hipotesis pertama diterima atau bisa dikatakan Ha diterima dan Ho ditolak dimana kedua variabel independen pada penelitian ini berpengaruh terhadap kinerja pegawai.

Hasil penelitian ini menunjukkan bahwa terdapat pengaruh positif dan signifikan antara budaya organisasi (X1) terhadap kinerja karyawan (Y) di RSUD K.H. Daud Arif Kuala Tungkal Jambi. Berdasarkan analisis regresi diketahui bahwa pengaruh budaya organisasi terhadap kinerja karyawan, terlihat bahwa t hitung sebesar 3.349 dengan signifikansi 0.002, serta t tabel sebesar 1.697. Taraf signifikan hasil sebesar 0,002 < 0,05 , yang berarti bahwa hipotesis dalam penelitian ini budaya organisasi berpengaruh positif dan signifikan terhadap kinerja karyawan di RSUD K.H. Daud Arif Kuala Tungkal Jambi. Hal ini terbukti bahwa taraf signifikan $\alpha<0,05$ dengan demikian Ho ditolak dan Ha diterima. Jadi kesimpulanya budaya organisasi berpengaruh positif dan signifikan terhadap kinerja karyawan. Dimana variabel budaya organisasi diukur dengan indikator 1) aspek kualitatif (basic), 2) aspek kuantitatif (shared) dan aspek terbentuknya, 3) assumption dan beliefs, 4) eksternal adaptation dan 5) internal integration.

Pengaruh budaya organisasi terhadap kinerja karyawan di di RSUD K.H. Daud Arif Kuala Tungkal Jambi dapat dijelaskan dengan beberapa faktor organisasi yang terbuka terhadap inisiatif dan inovasi mempengaruhi karyawan berpartisipasi dalam kegiatan di di RSUD K.H. Daud Arif Kuala Tungkal Jambi selain itu tujuan organisasi yang jelas bagi karyawan dan reward yang diberikan berdasarkan kinerja karyawan sehingga karyawan memperhatikan informasi mengenai perkembangan RSUD K.H. Daud Arif Kuala Tungkal Jambi.

Didukung penelitian Oskar (2015:67), hasil penelitian menunjukkan bahwa terdapat pengaruh yang positif antara variabel budaya organisasi terhadap efektivitas organisasi karyawan di PT. Budaya organisasi lebih banyak dipengaruhi oleh leader-leader soal komunikasi dan kreasi di dalam lingkungan kerja. Ketika para pemimpin ini adalah arsitek budaya organisasi, maka budaya yang sudah dibangun mempengaruhi gaya kepemimpinan (Schein, 2010). Sehingga seorang leader dalam membentuk budaya kerja nantinya akan membantu anggota mencapai tujuan yang ditetapkan bersama. Karena itu, budaya organisasi, kepuasan terhadap pekerjaan dan kepemimpinan sangat berhubungan.

Sisi lainya Variabel Good Corporate Governance yang menggunakan indikator ukuran Self Assessmen, Kelengkapan dokumen, Penyusunan makalah dan presentasi Observasi terhadap variabel kinerja karyawan di RSUD K.H. Daud Arif Kuala Tungkal Jambi berdasarkan hasil uji statistik t menunjukkan nilai nilai $\mathrm{t}$ hitung sebesar 2.067 dengan signifikansi 0,000, serta t tabel sebesar 1.697. Hasil tersebut menunjukkan bahwa hipotesis dalam penelitian ini Good Corporate Governance berpengaruh positif dan signifikan terhadap kinerja karyawan di RSUD K.H. Daud Arif Kuala Tungkal Jambi. Dimana ini terbukti bahwa taraf signifikan $\alpha<0,05$ dengan demikian Ho ditolak dan Ha diterima.

Hasil hipotesis tersebut bertolak belakang dengan penelitian yang dilakukan oleh Yuda Adestian (2014) yang menyatakan bahwa ukuran Good Corporate Governance tidak berpengaruh terhadap kinerja perusahaan dikarenakan dewan direksi sebagai manajemen senantiasa memiliki keinginan untuk meningkatkan kinerja perusahaan. Dengan adanya pemisahan peran dengan dewan komisaris, dewan direksi memiliki kuasa yang besar dalam mengelola segala sumber daya yang ada dalam perusahaan. Dewan direksi memiliki tugas untuk menentukan arah kebijakan dan strategi sumber daya yang dimiliki oleh perusahaan baik untuk jangka pendek maupun jangka panjang sehingga akan berusaha untuk meningkatkan kinerja perusahaan.

Perbedaan hasil penelitian ini dikarenakan Good Corporate Governance yang ada di RSUD K.H. Daud Arif Kuala Tungkal Jambi berjalan sebagaimana mestinya. Dimana seperangkat peraturan yang menetapkan hubungan antara pemangku kepentingan pengurus, pihak kreditur, pemerintah, karyawan serta 
para pemegang kepentingan internal dan eksternal lainnya sehubungan dengan hak-hak dan kewajiban mereka, atau dengan kata lain sistem yang mengarahkan dan mengendalikan perusahaan berjalan sebagaimana mestinya.

Uuntuk menjawab hipotesa kedua dari tujuan penelitian terdapat pengaruh atau tidaknya variabel budaya organisasi dan Good Corporate Governance secara simultan terhadap kinerja karyawan di RSUD K.H. Daud Arif Kuala Tungkal Jambi digunakan perhitungan uji hipotesa yang dilihat dari besarnya uji $\mathrm{F}$ pada tabel berikut:

Tabel 5. Uji Simultan (Uji F)

\begin{tabular}{|c|c|c|c|c|c|c|}
\hline Model & & Sum of Squares & $\mathrm{df}$ & $\begin{array}{l}\text { Mean } \\
\text { Square }\end{array}$ & $\mathrm{F}$ & Sig. \\
\hline 1 & $\begin{array}{l}\text { Regression } \\
\text { Residual } \\
\text { Total }\end{array}$ & $\begin{array}{l}248,670 \\
504,301 \\
752,971\end{array}$ & $\begin{array}{l}2 \\
31 \\
33\end{array}$ & $\begin{array}{l}124,335 \\
16,268\end{array}$ & 7,643 &, $002^{\mathrm{b}}$ \\
\hline
\end{tabular}

a. Dependent Variable: Kinerja Karyawan

b. Predictors: (Constant), CGC, Budaya organisasi

Hasil perhitungan pada tabel 4 membandingkan $\mathrm{f}_{\text {hitung }}$ dengan $\mathrm{f}_{\text {tabel }}$ dengan taraf signifikan $\alpha=0.05$. Dapat diketahui bahwa $\mathrm{f}_{\text {hitung }}$ sebesar 7,643 dengan membandingkan $\mathrm{f}_{\text {tabel }} \alpha=0,05$ dengan Df1 adalah 2 dan Df2 adalah 34-2-1=31, didapat $\mathrm{f}_{\text {tabel }}$ sebesar 3,30. $\mathrm{F}_{\text {hitung }}$ lebih besar dari $\mathrm{f}_{\text {tabel }}(7,643>3,30)$ maka Ho ditolak dan Ha diterima, berarti ada pengaruh yang signifikan antara variabel independen $(\mathrm{x})$ yakni budaya organisasi $\left(\mathrm{X}_{1}\right)$ dan Good Corporate Governance secara bersama-sama terhadap variabel dependen (y) yaitu kinerja karyawan. Dimana variabel kinerja karyawan diukur dengan indikator efektifitas, tanggung jawab, disiplin dan inisiatif.

Tidak bisa dipungkiri bahwa masing-masing variabel independen pada penelitian ini memiliki keterkaitan yang sangat erat dalam meningkatkan kinerja karyawan. Oleh karena itu kinerja karyawan dipengaruhi oleh Budaya Organisasi dan Good Corporate Governance secara bersama-sama. Maksudnya jika Budaya Organisasi tinggi dan Good Corporate Governance karyawan berjalan sebagai mestinya maka akan berdampak pada kinerja aryawan di RSUD K.H. Daud Arif Kuala Tungkal Jambi dan sebaliknya jika Budaya Organisasi rendah dan Good Corporate Governance tida berjalan sebagaimana mestinya maka kinerja karyawan juga berdampak menjadi buruk. Begitu juga apa yang terjadi dilapangan, karyawan di RSUD K.H. Daud Arif Kuala Tungkal Jambi yang memiliki budaya organisasi tinggi dan melaksanakan Good Corporate Governance maka akan berdampak pada kemajuan kinerja karyawan di RSUD K.H. Daud Arif Kuala Tungkal Jambi.

Penemuan dan pembahasan dari penelitian ini didukung oleh teori Tunggal (2013), good corporate governance adalah sistem yang mengatur, mengelola dan mengawasi proses pengendalian usaha untuk menaikkan nilai saham, sekaligus sebagai bentuk perhatian kepada stakeholders, karyawan dan masyarakat sekitar. Serta budaya organisasi yang ditanamkan pada karyawan mengikuti dengan apa yang telah ditetapkan suatu perusahaan.

\section{SIMPULAN}

Hasil perhitungan dan pembahasan yang telah dianalisis dalam penelitian ini dapat disimpulkan bahwa 1) secara parsial telah diperoleh perhitungan dan pembahasan bahwa variabel budaya organisasi (X1) berpengaruh positif secara signifikan terhadap kinerja karyawan $(\mathrm{Y})$ sehingga $\mathrm{H} 0$ ditolak dan $\mathrm{H} 1$ diterima dan untuk variabel good corporate governance (X2) diperoleh perhitungan dan pembahasan bahwa ada pengaruh yang signifikan terhadap kinerja karyawan (Y), sehingga $\mathrm{H} 0$ ditolak dan $\mathrm{H} 1$ diterima, dan 3) secara simultan budaya organisasi (X1) dan good corporate governance (X2), beperngaruh signifikan terhadap kinerja karyawan (Y), sehingga H0 ditolak dan H1 diterima

Adapun saran yang diharapkan dari hasil penelitian ini diantara lain adalah 1) Perlu disarankan kepada RSUD K.H. Daud Arif Kuala Tungkal Jambi untuk lebih meningkatkan kondisi budaya organisasinya dengan membudayakan kegiatan-kegiatan bersama berupa olah raga ataupun kegiatan keagamaan lainnya secara bersama-sama. Kemudian untuk mendukung good corporate governance, karyawan sebaiknya selalu mempunyai rasa memiliki terhadap rumah sakit, karyawan sebaiknya selalu perduli terhadap masalah yang terjadi dalam rumah sakit, karyawan sebaiknya selalu memiliki kelekatan emosional terhadap rumah sakit. 2) Dengan kebersamaan tersebut akan memperbaiki budaya organisasi dan juga good corporate governance. Dengan demikian. Kinerja Karyawan akan lebih meningkat lagi dan apabila Kinerja Karyawan meningkat, maka karyawan akan merasa puas dengan pencapaiannya. 3) Saran bagi peneliti selanjutnya yang tertarik melakukan penelitian serupa disarankan untuk menambah variabel penelitian, misalnya motivasi kerja, gaya kepemimpinan, budaya kerja, efektivitas karyawan, 
Azizah dan Muhammad Emmil, Pengaruh Budaya Organisasi dan Good Corporate Governance terhadap Kinerja Karyawan di RSUD K.H. Daud Arif Kuala Tungkal Jambi

komitmen afektif, dan lain-lain yang dapat berpengaruh terhadap Kinerja Karyawan.

\section{DAFTAR PUSTAKA}

Harsuko, Riniwati. 2011. Mendongkrak Motivasi dan Kinerja: Pendekatan Pemberdayaan SDM. Malang: UB Press

Kinicki, Angelo., dan Fugate. 2013. Organizational Behavior: Key Concepts, Skills and Best Practices. 5th Edition. New York: McGraw-Hill Education

Kurniawan, Ardeno. 2012. Audit Internal Nilai Tambah Bagi Organisasi Edisi Pertama. Yogyakarta:BPFE

Lilis, Ardini,. 2009. Analisis Perbandingan Pengaruh Langsung dan Tak Langsung Faktor Budaya Organisasi dan Komitmen Terhadap Kinerja Karyawan Pada UPTD Parkir Kota Surakarta. Sekolah Tinggi Ilmu Ekonomi Indonesia (STIESIA) Surabaya. Ekuitas. Vol. 13, No. 2; pg. 238-258.

Luthans, Fred. 2011. Organizational Behavior : An Evidence-Based Approach. New York: McGrawHill.

Mangkunegara. 2011. Manajemen Sumber Daya Perusahaan. Bandung: PT. Remaja Rosdakarya.

Monks, Robert dan Minow. N. 2003. Corporate Governance. Edisi Ketiga. Blackwell Publishing.

Pratiwi, Angrum. 2016. "Pengaruh Kualitas Penerapan Good Corporate Governance Terhadap Kinerja Keuangan pada Bank Umum Syariah. Skripsi. Samarinda : Fakultas Ekonomi dan Bisnis.

Prawirosentono, Suyadi 2010. Manajemen Sumber Daya Manusia; Kebijakan Kinerja Karyawan; Kiat Membangun organisasi Kompetitif era Perdagangan Bebas Dunia. BPFE; Jogyakarta

Reny Dyah dan Denies Priantinah. 2012. Pengaruh Good Corporate Governance dan Pengungkapan Corporate Social Responsibility Terhadap Nilai Perusahaan (Studi Empiris Pada Perusahaan yang Terdaftar di Bursa Efek Indonesia Periode 2007-2010), Jurnal Nominal, Vol. 1 No. 1

Robbins, Stephen P \& Judge, Timothy A. 2013. Organizational Behavior Edition 15. New Jersey: Pearson Education

Sinambela, Lijan Poltak. 2012. Kinerja Pegawai. Yogyakarta: Graha Ilmu

Susanto. 2006. Strategi Organisasi. Yogyakarta: Amara Books.

Tunggal, H. S. 2013. Internal Auditing \& Corporate Governance. Jakarta: Havarindo.

Walker Jr, Mullins, John W dan Orville C. 2013. Marketing Management: A Strategic DecisionMaking Approach, 8th Edition, McGraw-Hill International Edition.

Wibowo. 2011. Manajemen Kinerja. Jakarta: Raja Grafindo Persada.
Zarkasy,M.Wahyudin. 2008. Good Corporate Governance Pada Badan Usaha Manufaktur, Perbankan dan Jasa Keuangan Lainya. Bandung: Alfabeta 